\title{
Glacier area changes in the Pumqu river basin, Tibetan Plateau, between the 1970s and 2001
}

\author{
Rui JIN, ${ }^{1}$ Xin $\mathrm{LI}^{1}{ }^{1}$ Tao $\mathrm{CHE}^{1}{ }^{1}$ Lizong WU, ${ }^{1}$ Pradeep $\mathrm{MOOL}^{2}$ \\ ${ }^{1}$ Cold and Arid Regions Environmental and Engineering Research Institute, Chinese Academy of Sciences, \\ 322 Donggang West Road, Lanzhou 730000, China \\ E-mail: jinrui@Izb.ac.cn \\ ${ }^{2}$ International Centre for Integrated Mountain Development, GPO Box 3226, Khumaltar, Kathmandu, Nepal
}

\begin{abstract}
Glacier area changes in the Pumqu river basin, Tibetan Plateau, between the 1970s and 2001 are analyzed, based on the Chinese Glacier Inventory and ASTER images. A new glacier inventory is obtained by visually interpreting the remote-sensing images and the digital elevation model. By comparing the two inventories, glacier area changes over the past 30 years are revealed. The results show that the area loss is about $9.0 \%$ and the shrinkage trend continues according to the meteorological data.
\end{abstract}

\section{INTRODUCTION}

Glacial change, particularly in mountainous regions, is a sensitive indicator of global climate. It has been suggested that further shrinkage of glaciers must occur with a warmer climate (Oerlemans and Fortuin, 1992; Dyurgerov and Meier, 2000), and many mountain glaciers will disappear during this century in a warming climate scenario (Haeberli and Hoelzle, 1995; Shi, 2001).

According to the Chinese Glacier Inventory (CGl; Wu and $\mathrm{Li}, 2004)$, there are 46252 glaciers in China covering an area of $59402 \mathrm{~km}^{2}$. The total glacier area in China is about $8.7 \%$ of the global area covered by glaciers $\left(680000 \mathrm{~km}^{2}\right)$ outside Antarctica and Greenland (Meier and Bahr, 1996) and $47.6 \%$ of the area covered by glaciers in Asia $\left(124900 \mathrm{~km}^{2}\right)$. Glaciers can indicate regional and global climatic change and they can serve as the major water source and runoff recharge for the arid and semi-arid regions of western China. But, in recent years, glacier shrinkage has been speeding up in such mountain areas as the Himalaya, Qilian Shan and Tien Shan (Shi, 2001).

The Himalaya is an especially sensitive area for global climatic change (Thompson and others, 1989). It contains one of the largest concentrations of glaciers outside the polar regions and glacier changes are thought to be more rapid in the Himalaya than in many other places because of the extraordinary warming trend evident on the Qinghai-Tibetan Plateau. These changes are expected to continue during this century (Ageta and Kadota, 1992; Nakawo and others, 1997). In addition, glacier retreat in the Himalaya will potentially influence human welfare in downstream regions because it will result in glacial lake outburst floods, which often have catastrophic effects on the community, economy and sustainable development of Nepal. Supported by the United Nations Environment Programme, the International Centre for Integrated Mountain Development has launched projects to study glacier change and to identify the potentially dangerous glacial lakes in the Hindu KushHimalaya (Mool and others, 2001). The work presented here is a report of one of those projects. The Pumqu river basin was chosen as our research area. It is located in the southern part of the Tibetan Plateau, neighboring Nepal. The geographic extent is $27^{\circ} 49^{\prime}-29^{\circ} 05^{\prime} \mathrm{N}, 85^{\circ} 38^{\prime}-88^{\circ} 57^{\prime} \mathrm{E}$, with an area of approximately $25307 \mathrm{~km}^{2}$ and a mean elevation around $4500 \mathrm{~m}$ (Fig. 1). There are a large number of glaciers covering an area of about $1400 \mathrm{~km}^{2}$ and more than 200 glacial lakes. According to the guidelines of the World Glacier Inventory, the whole basin was divided into five subbasins with codes 5O193, 5O194, 50196, 50197 and 50198 (Fig. 1).

\section{DATA AND METHODS}

The data used in this work include:

1. Fifteen topographic maps at a scale of $1: 100000$ and 47 topographic maps at 1:50000, based on aerial surveys from 1974 to 1983 (Table 1). These were used as the baseline to study glacier change. These maps were also the 'working' documents of the CGI, and the glacier outlines on these maps were refined with the help of aerial photographs taken from 1970 to 1980 (Table 1). Thus, the glacier outlines on the topographic maps reflect the state of glaciers in the 1970s.

2. CGI XI (Mi and others, 2002) was used as a complementary data source.

3. Sixteen scenes of Advanced Spaceborne Thermal Emission and Reflection Radiometer (ASTER) images, mainly in October 2001 with low cloud cover, were acquired. The regions where the ASTER images are unavailable were covered by two scenes of the China-Brazil Earth Resources Satellite (CBERS).

4. A digital elevation model (DEM) derived by digitizing the contour lines from topographic maps at the scale of $1: 50000$ was generated to derive relative parameters.

The ASTER and CBERS images with low snow cover that are free of cloud are suitable for identifying glaciers. Least snow cover generally occurs during the summer from June to August in the Himalaya. But during this season, monsoon cloud always blocks the view. In this work, most of the images were acquired in October 2001 under conditions of low seasonal snow cover and little cloud (Table 2).

False-color composites were produced using ASTER L1B data with $15 \mathrm{~m}$ resolution and CBERS. Geo-reference was performed using Earth Resource Data Analysis System imagery. The registration accuracy was within one pixel in most regions. The glacier outlines in the 1970 s were 


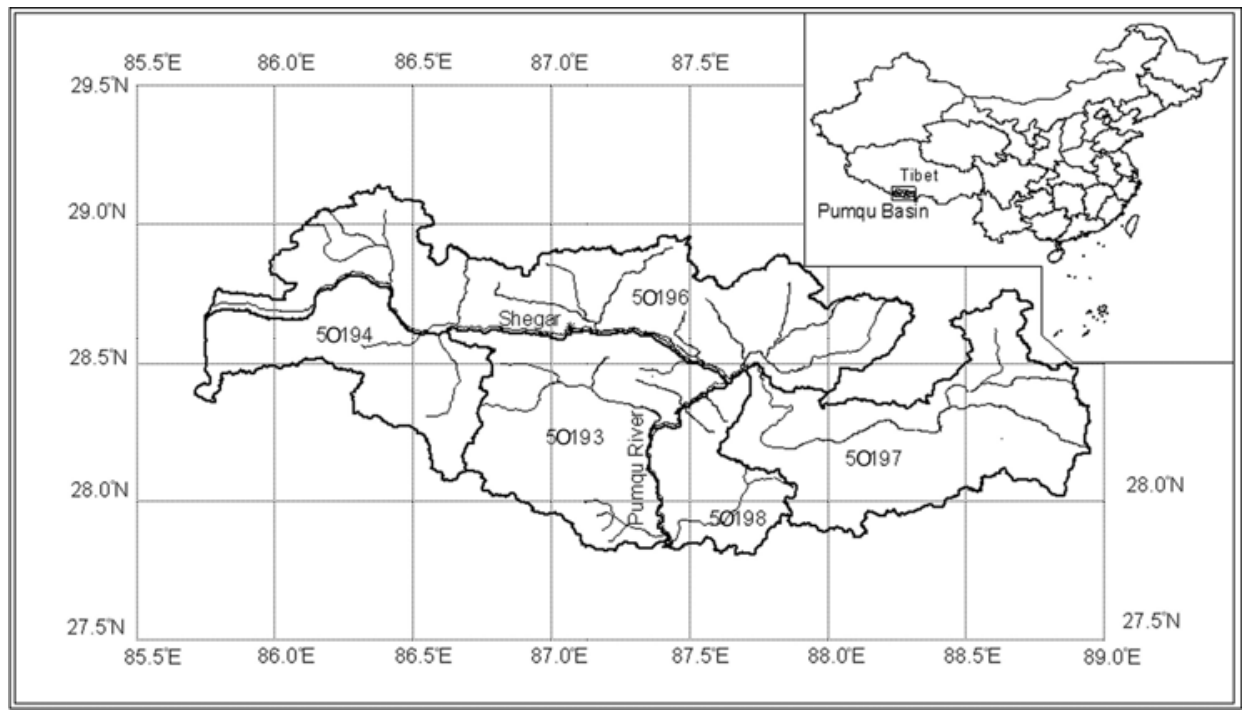

Fig. 1. Map of the Pumqu river basin, Tibetan Plateau, showing the different sub-basins.

obtained from the 'working' topographic maps and those in 2001 were derived from ASTER and CBERS images by manual interpretation.

Glacier attributes of the new inventory, especially those that are relatively stable (e.g. orientation and glacier type) were duplicated directly from the old inventory. Parameters related to height (e.g. the highest elevation, mean elevation and elevation of glacier tongue) were obtained from the DEM by overlaying the glacier outlines. Glacier area was computed using ArcView.

We used manual interpretation in this work which, though low in efficiency, is considered a more accurate but less objective method. There may be misinterpretation resulting from snow cover, debris cover and shading, so experience and knowledge of the physical characteristics of the glaciers are necessary. The texture and distribution characteristics of snow and glacier ice are important indicators for the interpretation. Glaciers appear white to light-blue in color, with linear and regular shapes having fine to medium texture. The distinct linear and dendritic pattern associated with slopes and valley floors in the high mountains covered with seasonal snow can be distinguished from glaciers.

Table 1. The type, scale and year of data sources for the 1970s glacier inventory

\begin{tabular}{ll}
\hline Sub-basin & $\begin{array}{l}\text { Data source of glacier inventory in } \\
1970 \mathrm{~s}\end{array}$
\end{tabular}

$5 \mathrm{O} 193 \mathrm{~A}$

$50193 \mathrm{~B}$

5O194A, 5O194B

5O194C, 5O194D, 5O194E

5O196A, 5O196B

5O197A

5O197B

5O198A, 5O198B, 5O198C 5O198D, 5O198E

AM-10-80, AP-6-74

AM-5-80, AP-4-74

AM-10-80, AP-6-74

AM-10-81, AP-6-70

AM-10-74, AP-6-70

AM-5-82, AP-6-80

AM-5-80, AM-5-83, AP-6-74,

AP-6-78, AP-6-80

AM-5-80, AP-6-74

AM-5-79, AP-6-74
Debris cover is an issue because of its spectral similarity to the surrounding terrain (Williams and others, 1991; Paul and others, 2002). In this work, using manual interpretation, we were able to detect some of the moraine-covered glacier ice using experienced-based indicators such as white to light-grey color and concave/convex surface.

Shading by terrain also influences the interpretation, especially in high mountain areas in winter, where and when terrain can cast strong shadows on glaciers. In this work, we rely on experience and old glacier inventories to deal with shadows.

\section{RESULTS}

Data about glacier distributions and changes in the study area between the 1970s and 2001 can be summarized as follows:

There were a total of 999 glaciers in the Pumqu river basin in the 1970s. They were categorized into seven classes by area. The glaciers with areas $<1 \mathrm{~km}^{2}$ made up $15.8 \%$ of the total glacier area, while larger glaciers $>1 \mathrm{~km}^{2}$ accounted for $84.2 \%$ (Fig. 2). The results show that while small glaciers predominate in numbers, larger glaciers account for most of the total area.

Comparison of glacier area in the two periods shows that the glaciers are in rapid retreat (Table 3). Glacier numbers in the Pumqu river basin had shrunk to 900 by 2001, i.e. about $10 \%$ of them had disappeared. The total area was reduced

Table 2. ASTER image dates

Image date Number of scenes

21 Feb 2001

10 May 2001

12 Oct 2001

13 Oct 2001

14 Oct 2001

15 Oct 2001

25 Oct 2001

Note: AP/AM-XX-YY: AP: aerial photo; AM: topographic map based on aerial survey; $\mathrm{XX}$ : data scale in $1: \mathrm{XX0} 000 ; \mathrm{YY}$ : measurement year. 

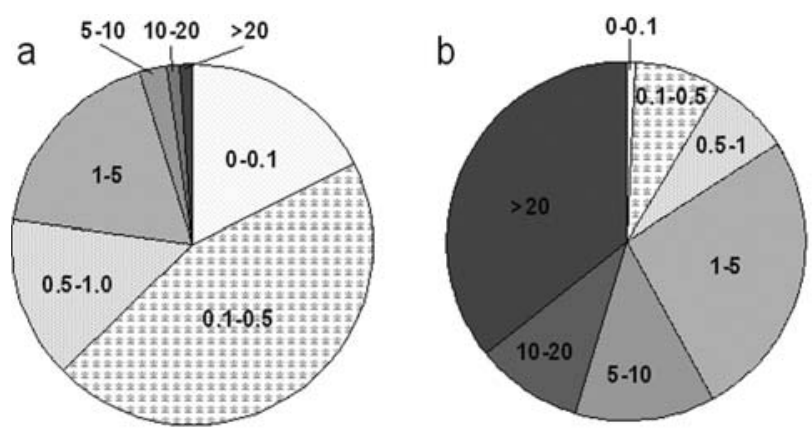

Fig. 2. Pie chart indicating the proportion of (a) the total number of glaciers, and (b) the total area of glaciers, within each glacier size category (labeled in $\mathrm{km}^{2}$ ) for the Pumqu river basin in the 1970 s.

by $9 \%$. The total measurement accuracy depends on registration technique, the pixel resolution of the image and the accuracy of glacier position shown on the map (Hall and others, 2003). The area uncertainty due to registration $\left(15 \mathrm{~m} \times 15 \mathrm{~m}=0.000225 \mathrm{~km}^{2}\right)$ and pixel resolution $\left(2 \times 15 \mathrm{~m} \times 15 \mathrm{~m} \times \sqrt{1}=0.000450 \mathrm{~km}^{2}\right) \quad($ Williams and others, 1997; Hall and others, 2003) is very small and can be ignored in the total uncertainty. According to the CGI, the uncertainty of the glacier area on topographic maps is $<5 \%$. So the total uncertainty of each sub-basin and the whole Pumqu river basin can be estimated by

Uncertainty $=\sqrt{\left(S_{1} \times 5 \%\right)^{2}+\left(S_{2} \times 5 \%\right)^{2}+\cdots+\left(S_{n} \times 5 \%\right)^{2}}$, where $S_{n}$ is glacier area and $n$ is number of glaciers.

As has been found by other investigators, the smaller the glaciers, the larger their percentage change in area (Shi, 2001; Kulkarni and Bahuguna, 2002; Paul and others, 2002). In Figure 3 the 797 glaciers with area loss noted in the 2001 inventory are analyzed. The results demonstrate the same findings, indicating the larger sensitivity of small glaciers to climatic effects. Most small glaciers in the region shrank drastically or even disappeared. The reason for the higher sensitivity of small glaciers is that when the equilibrium-line altitude increases, it can extend above the altitude of many of the small glaciers, whereas the debris on the tongues of large glaciers often prevents them melting.

\section{DISCUSSION AND CONCLUSIONS}

Glaciers change as a consequence of climate fluctuations. Among many factors, snowfall and summer temperature are the two major ones controlling glacier development on the

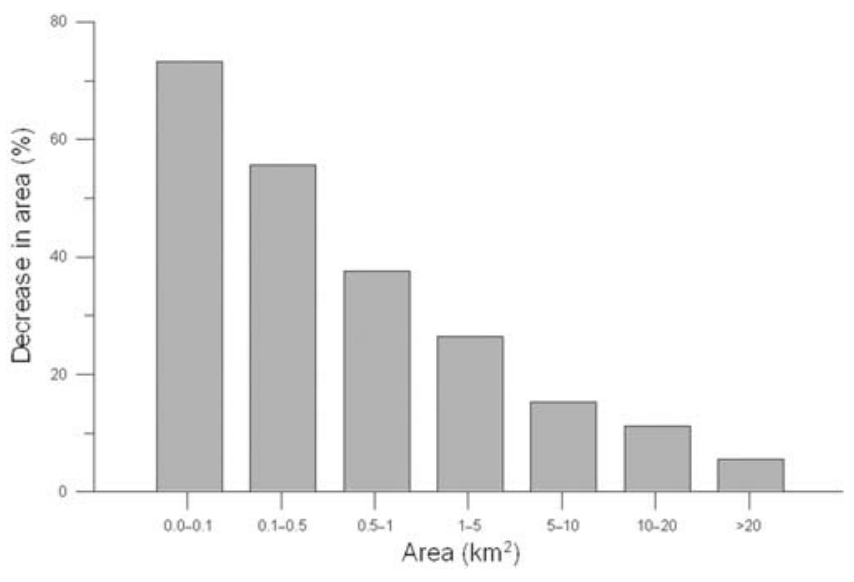

Fig. 3. Decrease in area of each class of glaciers (categorized by area) in the Pumqu river basin between the 1970s and 2001.

Qinghai-Tibetan Plateau. Summer temperature dictates ablation, while snowfall influences accumulation. Investigations have shown that the increase in air temperature during the last century has started to affect glaciers in the Himalaya (Shi and others, 2000; Kulkarni and Bahuguna, 2002).

There is only one meteorological station, Shegar $\left(28^{\circ} 38^{\prime} \mathrm{N}, 87^{\circ} 05^{\prime} \mathrm{E}\right)$, in the study area. We collected annual mean temperature and precipitation data at this station from 1959 to 2000. There is a clear increasing trend in temperature while the annual precipitation varied significantly and showed a slight increasing trend (Fig. 4). Even when precipitation increases, in a climate-warming scenario it is possible for glacier recession to occur. The equilibrium line can be expected to rise by $100-160 \mathrm{~m}$ with the $1^{\circ} \mathrm{C}$ increase in mean air temperature from June to August. In order for the equilibrium line to remain unchanged, the annual increase in precipitation would need to be above 40\%, even 100\% (Kang, 1996; Shi and others, 2000). This kind of increase is almost impossible because the mean annual precipitation has been $247 \mathrm{~mm}$ during the last 40 years. Thus, with the current temperature increase, the glaciers are expected to continue to shrink.

The main consequence of glacier recession in the Himalaya is that glacier retreat might prompt frequent glacial lake outburst floods, often with catastrophic effects downstream. We investigated changes in glacial lakes in the region and found larger areas than in the 1970s. Among the 225 glacial lakes listed in the inventory, 24 in the Pumqu river basin were identified as potentially dangerous. Criteria

Table 3. Glacier numbers and areas, and percentage changes in each sub-basin of the Pumqu river basin, for the period 1970 s-2001

\begin{tabular}{|c|c|c|c|c|c|c|}
\hline \multirow[t]{3}{*}{ Sub-basin } & \multirow{3}{*}{$1970 \mathrm{~s}$} & \multicolumn{3}{|c|}{ Glacier numbers } & \multicolumn{2}{|c|}{ Glacier area } \\
\hline & & 2001 & Change & $1970 \mathrm{~s}$ & 2001 & Change \\
\hline & & & $\%$ & $\mathrm{~km}^{2}$ & $\mathrm{~km}^{2}$ & $\%$ \\
\hline 50193 & 358 & 333 & -7.0 & $689 \pm 7$ & $654 \pm 7$ & -5.0 \\
\hline 50194 & 110 & 113 & 2.7 & $294 \pm 4$ & $282 \pm 4$ & -4.2 \\
\hline 50196 & 58 & 37 & -36.2 & $13.4 \pm 0.2$ & $4.2 \pm 0.1$ & -68.6 \\
\hline 50197 & 226 & 222 & -1.8 & $281 \pm 2$ & $259 \pm 2$ & -7.6 \\
\hline 50198 & 247 & 195 & -21.1 & $184 \pm 1$ & $131 \pm 1$ & -29.2 \\
\hline Total & 999 & 900 & -10.0 & $1462 \pm 9$ & $1330 \pm 8$ & -9.0 \\
\hline
\end{tabular}




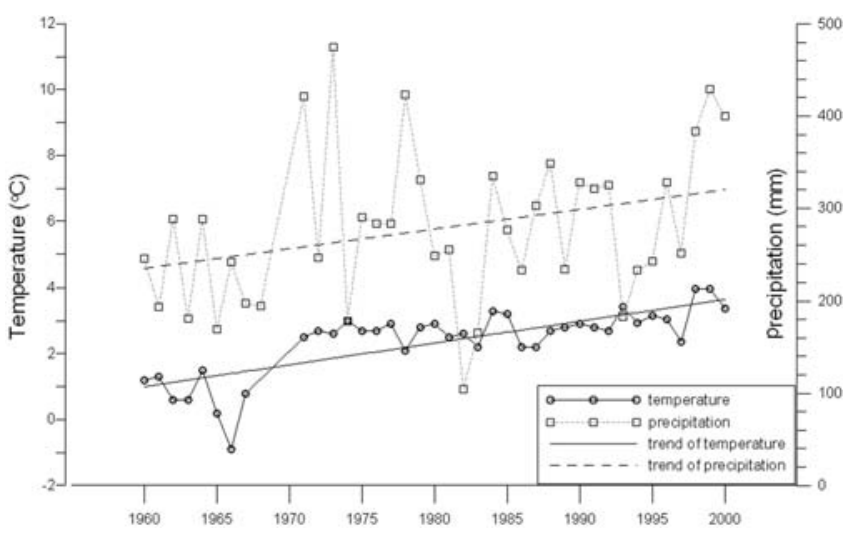

Fig. 4. Variations in annual mean air temperature and annual precipitation during the last 40 years at the Shegar meteorological station $\left(28^{\circ} 38^{\prime} \mathrm{N}, 87^{\circ} 05^{\prime} \mathrm{E} ; 4300 \mathrm{~m}\right)$.

examined included lake type, distance from the mother glacier, slope, change in rate of mother glacier, etc. (Che and others, in press).

The work presented here shows that over the past 30 years the glaciers of the Pumqu river basin have been in rapid recession. The number of glaciers in the Pumqu river basin has decreased by about $10 \%$, from 999 to 900 between the 1970s and 2001. The total glacier area has reduced by $9 \%$.

\section{ACKNOWLEDGEMENTS}

We thank D.S. Mi for instruction in the manual interpretation of glacier data, and Scientific Editor R. Naruse and two reviewers for helpful comments. The ASTER images used in the work were provided by the Global Land Ice Measurements from Space (GLIMS) project. This work was supported by the National Science Foundation of China 90202014 and by the China Key Basic Research Project 2001CB309400.

\section{REFERENCES}

Ageta, Y. and T. Kadota. 1992. Predictions of changes of glacier mass balance in the Nepal Himalaya and Tibetan Plateau: a case study of air temperature increase for three glaciers. Ann. Glaciol., 16, 89-94.

Che, T., R. Jin, X. Li and L.Z. Wu. In press. The analysis of the glacial lake change and potentially dangerous glacial lake during the recent two decades in Pumqu basin, Tibet. Arct. Antarct. Alp. Res.

Dyurgerov, M.B. and M.F. Meier. 2000. Twentieth century climate change: evidence from small glaciers. National Academy of Sciences Proceedings (PNAS), 97(4), 1406-1411.
Haeberli, W. and M. Hoelzle. 1995. Application of inventory data for estimating characteristics of and regional climate-change effects on mountain glaciers: a pilot study with the European Alps. Ann. Glaciol., 21, 206-212.

Hall, D.K., K.J. Bayr, W. Schöner, R.A. Bindschadler and J.Y.L. Chien. 2003. Consideration of the errors inherent in mapping historical glacier positions in Austria from ground and space (1893-2001). Remote Sens. Environ., 86, 566-577.

Kang, E. 1996. [Characteristics of energy balance and computation on the mass balance of the high-Asia cryosphere.] J. Glaciol. Geocryol., 18, 12-22. [In Chinese with English abstract.]

Kulkarni, A.V. and I.M. Bahuguna. 2002. Correspondence. Glacial retreat in the Baspa basin, Himalaya, monitored with satellite stereo data. J. Glaciol., 48(160), 171-172.

Meier, M.F. and D.B. Bahr. 1996. Counting glaciers: use of scaling methods to estimate the number and size distribution of glaciers of the world. CRREL Spec. Rep. 96-27, 89-94.

Mi, D. S., Z.C. Xie, X.R. Luo, Q.H. Feng, M.G. Ma, and D.M. Jin. 2002. [Glacier inventory of China: XI the Ganga Drainage Basin and XII Indus Drainage Basin.] Xi'an, Xi'an Cartographic Publishing House.

Mool, P.K., S.R. Bajracharya and S.P. Joshi. 2001. Inventory of glaciers, glacial lakes and glacial lake outburst floods: monitoring and early warning systems in the Hindu Kush-Himalayan region, Nepal. Kathmandu, International Centre for Integrated Mountain Development.

Nakawo, M., K. Fujita, Y. Ageta, K. Shankar, A.P. Pokhrel and Y. Tandong. 1997. Basic studies for assessing the impacts of the global warming on the Himalayan cryosphere, 1994-1996. Bull. Glacier Res., 15, 53-58.

Oerlemans, J. and J.P.F. Fortuin. 1992. Sensitivity of glaciers and small ice caps to greenhouse warming. Science, 258(5079), 115-117.

Paul, F., A. Kääb, M. Maisch, T. Kellenberger and W. Haeberli. 2002. The new remote-sensing-derived Swiss glacier inventory. I. Methods. Ann. Glaciol., 34, 355-361.

Shi, Y. 2001. [Estimation of the water resources affected by climatic warming and glacier shrinkage before 2050 in western China.]. J. Glaciol. Geocryol., 23(4), 333-341. [In Chinese with English summary.]

Shi, Y.F., M.H. Huang, T.D. Yao and Y.X. Deng. 2000. [Mass balance and fluctuation of glaciers.] In [Glaciers and their environments in China - the present, past and future]. Beijing, Science Press, 101-131. [In Chinese.]

Thompson, L.G. and 9 others. 1989. Holocene-Late Pleistocene climatic ice core records from Qinghai-Tibetan Plateau. Science, 246(4929), 474-477.

Williams, R.S., Jr, D.K. Hall and C.S. Benson. 1991. Analysis of glacier facies using satellite techniques. J. Glaciol., 37(125), 120-128.

Williams, R.S., Jr, D.K. Hall, O. Sigurdsson and J.Y.L. Chien. 1997. Comparison of satellite-derived with ground-based measurements of the fluctuations of the margins of Vatnajökull, Iceland, 1973-92. Ann. Glaciol., 24, 72-80.

Wu, L.Z. and X. Li. 2004. [China glacier information system.] Beijing, Ocean Press of China. [In Chinese.] 